\title{
Image Contrast Improvement Based on Differential Gray-levels Histogram
}

\author{
Fumihiko Saitoh Member (Gifu University)
}

Keywords : image contrast improvement, gray-scaled image, differential gray-level, Look-Up-Table

This paper proposes a method for improving contrast of a gray-scaled image based on local differential gray-levels. Most conventional methods for contrast improvement convert gray-levels according to a distribution of gray-levels measured in an objective image. On the other hand, the proposed method uses differential gray-levels as a spatial feature for converting gray-levels.

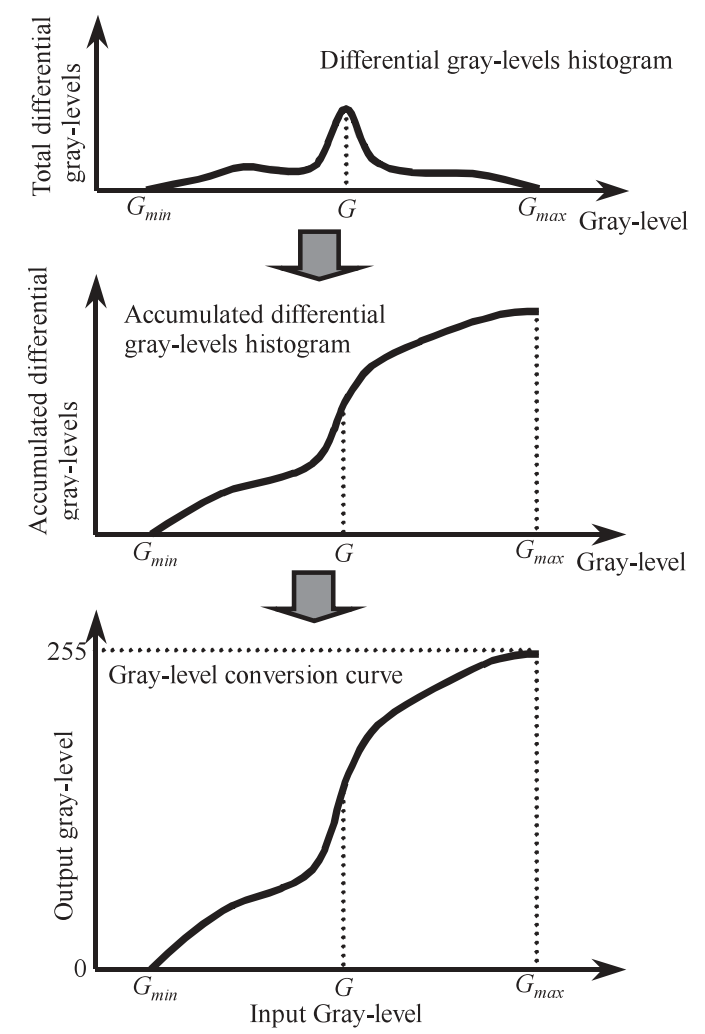

Fig. 1. Generation of gray-level conversion curve from differential gray-levels histogram.

The proposed method generates a gray-levels conversion curve between an input image and an output image from a differential gray-levels histogram as shown in Fig.1. The horizontal axis of the differential gray-levels histogram is gray-levels and the vertical axis is total differential gray-level of each gray-level. Here, the differential gray-level means a linear differential value in a local image area. An accumulated gray-levels histogram is also generated by accumulating values in the differential gray-levels histogram sequentially as shown in Fig.1. Next, a gray-levels conversion curve is generated by normalizing the range of the vertical axis of the accumulated gray-levels histogram in order to maximum the dynamic range of gray-levels. The gray-levels near $G$ that has a large frequency in the differential gray-levels histogram are extended widely between input image and output image because the gradient in the accumulated differential gray-levels histogram becomes steep near the gray-level $G$. Namely, the difference of gray-levels is expanded especially at edge parts in an input image.

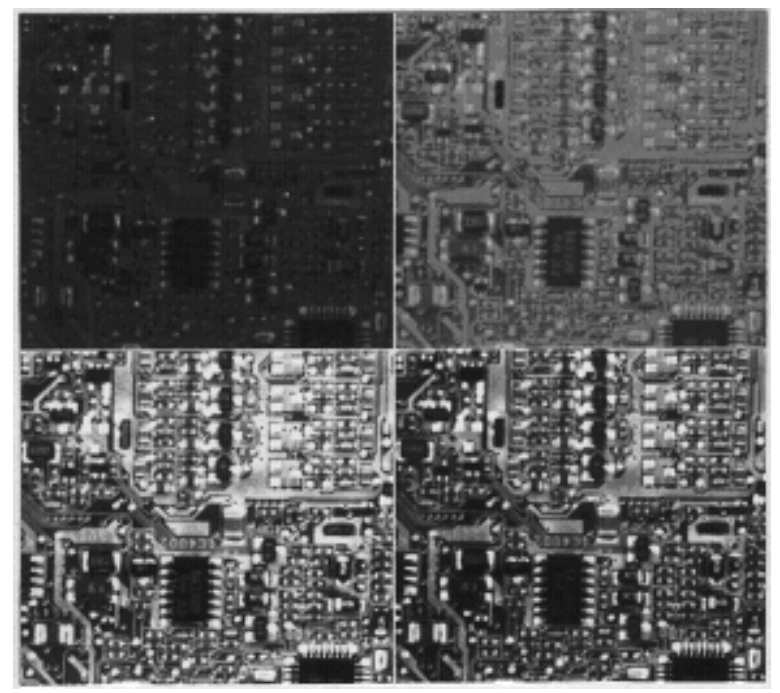

Fig. 2. Contrast improved images (upper-left: linear gray-level conversion, upper-right: histogram normalization, lower-left: histogram equalization, lower-right: proposed method).

Fig.2 shows an example of contrast improved image. The left-upper is a result by the linear gray-level conversion, the right-upper is a result by the histogram normalization, the left-lower is a result by the histogram equalization and the right-lower is a result by the proposed method. The proposed method generated the natural images with enhanced contrast.

Table1 shows DV(Detail Variance) and $B V$ (Background Variance) of the generated images by the conventional methods and the proposed method. The resultant images by the proposed method are assumed to have good and natural contrast because the proposed method (DG: Differential Gray-level) recorded higher $D V$ and lower $B V$ in comparison with the conventional methods.

Table 1. $\quad D V$ and $B V$ of resultant images.

\begin{tabular}{|c|c|c|c|c|c|c|}
\hline Image & $\begin{array}{l}\text { DV/ } \\
\text { BV }\end{array}$ & $\begin{array}{c}\text { Original } \\
\text { image }\end{array}$ & LGC & $\mathrm{HN}$ & $\mathrm{HE}$ & DG \\
\hline \multirow{2}{*}{ (a)connector } & DV & 160.4 & 225.8 & 251.8 & 239.9 & 390.8 \\
\hline & BV & 11.9 & 17.4 & 32.9 & 40.3 & 28.7 \\
\hline \multirow{2}{*}{ (b)motor } & DV & 444.3 & 439.5 & 495.0 & 428.5 & 551.6 \\
\hline & BV & 13.9 & 13.9 & 16.7 & 26.7 & 19.6 \\
\hline \multirow{2}{*}{ (c)floppy } & DV & 106.7 & 322.5 & 385.2 & 656.1 & 689.7 \\
\hline & BV & 3.5 & 41.2 & 40.6 & 69.7 & 34.6 \\
\hline \multirow{2}{*}{ (d)children } & DV & 277.1 & 423.7 & 435.0 & 360.2 & 586.4 \\
\hline & BV & 21.2 & 24.3 & 24.8 & 34.5 & 20.7 \\
\hline \multirow{2}{*}{ (e)pattern } & DV & 237.5 & 732.0 & 720.8 & 1137.1 & 1369.6 \\
\hline & BV & 44.5 & 47.3 & 47.1 & 47.2 & 40.0 \\
\hline \multirow{2}{*}{ (f)circuit } & DV & 197.7 & 325.6 & 296.3 & 1425.2 & 1205.8 \\
\hline & BV & 23.0 & 38.3 & 49.0 & 41.7 & 35.6 \\
\hline
\end{tabular}




\title{
濃度勾配ヒストグラムによる画像のコントラスト改善 \\ 正 員 斉藤 文彦 ${ }^{*}$

\author{
Image Contrast Improvement Based on Differential Gray-levels Histogram
} \\ Fumihiko Saitoh ${ }^{*}$, Member
}

\begin{abstract}
When a captured image does not have good contrast, a method for improving its contrast that converts gray-levels based on the distribution of gray-levels included in the image is generally applied. A resultant image with good contrast does not always generated because the conventional method does not use a spatial feature included in an input image. This paper proposes a method for contrast improvement that can enhance differential gray-levels in an image in order to generate a resultant image with clearness and good contrast. The proposed method determines a gray-level of each pixel according to a Look-up-table generated from a histogram to represent a distribution of differential gray-levels. The experimental results show that the resultant images with natural and clear contrast were generated by the proposed method.
\end{abstract}

キーワード：画像コントラスト改善, 濃淡画像, 濃度微分, LUT

Keywords : image contrast improvement, gray-scaled image, differential gray-level, Look-Up-Table

\section{1. はじめに}

カメラによって画像を撮影する際, コントラストの良好 な画像を取得することが重要な要件となる。しかし，外光 や照明環境，撮影に用いる光学系や機材等の影響によって， 必ずしも良好なコントラストが得られるとは限らない。こ のような場合, 一般的にソフトウェアによるコントラスト 改善が行われる ${ }^{(1) \sim(6)}$ 。コントラスト改善処理では, 画像に 含まれる濃度のダイナミックレンジを広げることが重要で ある。しかし，画像全体では充分なダイナミックレンジが 確保されているにもかかわらず, 暗部や明部を示す濃度階 調に多くの画素が集中しているような場合は，コントラス 卜改善が効果的に働かないことがある。また，対象となる 画像に応じて, 自動的に処理が行われ，良好な結果画像が 得られることが望ましい。すなわち，利用者が外部からパ ラメータを与えることなく，視覚的にコントラスト感の高 い画像を簡便に生成できる手法が求められる。

本論文では，画像の局所的な濃度勾配に着目したコント ラスト改善手法を提案する。従来の多くのコントラスト改 善手法では，画像に含まれる濃度の分布情報を基に濃度変 換を行うのに対して，提案手法では，濃度勾配という空間 的特徵を利用して濃度変換を行う。画像の濃度ダイナミッ クレンジを広げるとともに，特に画像内に存在する対象物 のエッジ部分を強調することによって, 視覚的にコントラ

岐阜大学工学部

干 501-1167 岐阜市柳戶 1-1

Faculty of Engineering, Gifu University,

1-1 Yanagido, Gifu-city 501-1167
ス卜感の高い結果画像を得ることができる。また，外部か らのパラメータを不要とした自動的なコントラスト改善を 可能とする。

\section{2. 画像のコントラスト 改善}

画像のコントラスト改善手法としては, 図 1 に示すよう に, 入力画像に含まれる濃度範囲を表示可能な最大濃度範 囲に線形に拡張する濃度線形変換法 ${ }^{(1)}{ }^{(6)}$ が一般的である。 この手法の利点は, 視覚的に自然な出力画像が自動的にか つ高速に得られることである。しかし，入力画像が広い濃 度範囲を持つにもかかわらず, 暗部や明部を示す濃度に集 中的に多くの画素が分布している場合，コントラスト改善 の効果がほとんど期待できない。

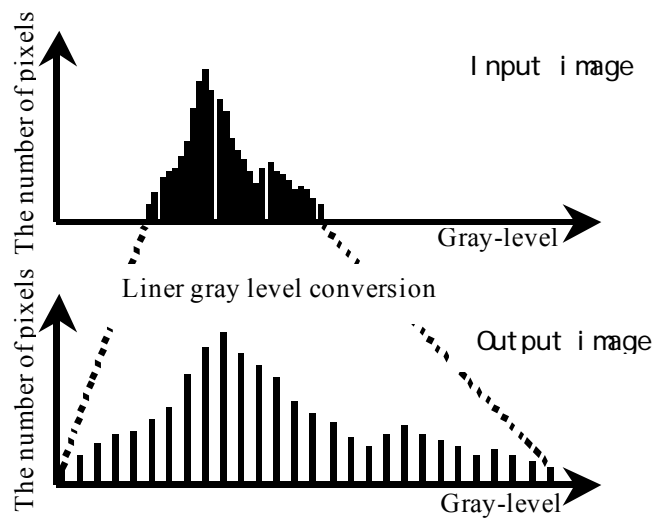

図 1 濃度線形変換法

Fig. 1. Linear gray level conversion. 


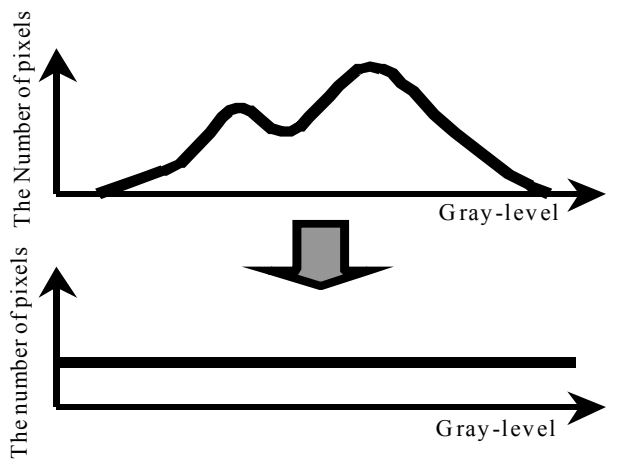

図 2 ヒストグラム均等化法

Fig. 2. Histogram equalization.

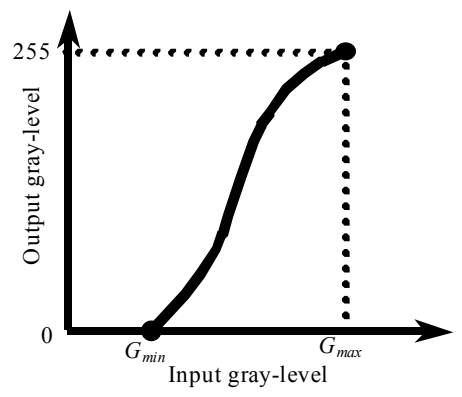

図 3 LUT による濃度変換

Fig. 3. Gray-level conversion using LUT.

これに対して，ヒストグラム均等化法 ${ }^{(3) \sim(6)}$ は，图 2 に示 すように，濃度分布ヒストグラムが均一化されるように各 画素の濃度值を変換する手法であり，濃度分布のエントロ ピーを最大化できるため，顕著なコントラスト強調効果が 得られる場合が多い。しかし，入力画像によっては，強調 度合が大きすぎて不自然な出力画像となったり，濃度の均 一性が高い領域ではノイズが目立つ場合がある。

また，濃度の分布状態が正規分布に近くなるように各画 素の濃度值を変換する手法 ${ }^{(7)}$ もあり，比較的自然な出力画像 が得られるが，濃度線形変換法と同樣に，画像によっては 効果的なコントラスト改善が行われない。

代表的な以上の従来手法は，いずれも外部からパラメー 夕を与える必要がなく，入力画像を与えるだけで自動的に 結果画像が得られるという利点がある。一方，入力画像に 含まれる特定の濃度範囲を伸張する代表的な方法として， ガンマ変換 ${ }^{(8)}$ がある。また, 图 3 に示すような入力画像と出 力画像間の濃度の変換関数 (LUT: Look-Up-Table) を設定し， この関数曲線に従って, 出力画像の各画素の濃度值を得る 方法 ${ }^{(8)}$ がある。これらの手法は, 入力画像に応じてガンマ係 数や濃度変換曲線が設定できるため, 効果的なコントラス 卜改善が期待できるが, 人間の視覚による確認作業と良好 な結果を得るための試行錯誤が必要となる。

以上に述べた従来手法では, 入力画像に含まれる濃度の 分布状態に基づいて各画素の濃度值を変換している。濃度 分布は, 画像のコントラストに関係する重要な情報である

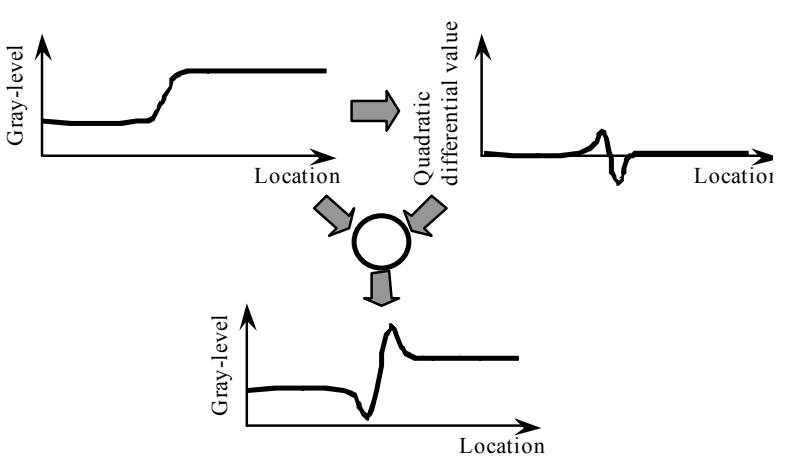

図 4 画像の鮮鋭化

Fig. 4. Unsharp masking of image.

が，画像の空間的な特徵は含まれていない。コントラスト 改善では, 画像の濃度ダイナミックレンジを広げるととも に，背景領域に対して画像内に含まれる対象物が明瞭であ ることが求められる。一方, コントラスト改善処理とは異 なるが，アンシャープマスキングによって画像に含まれる エッジを強調する鮮鋭化処理がある ${ }^{(9)}$ 。図 4 に示すように， 入力画像の濃度に関する 2 次微分值を入力画像の濃度值か ら減じる。この処理によって, 入力画像内で濃度が局所的 に変化する部分における濃度変化分が増大されるため, 視 覚的に鮮明な結果画像か得られる。このように,コントラ スト感は, 濃度分布だけでなく, 対象物の輪郭部分の鮮明 さによる影響も大きく受けると考えられる。但し，上記の 鮮鋭化処理では, 入力画像内の各画素の濃度值に関する大 小関係は保持されない。すなわち，図 4 に示したエッジの 両端付近では, 画素間で濃度值の大小関係が反転する場合 が起こりえる。これに対して, 図 3 に示した濃度変換関数 によるコントラスト改善手法では, 变換関数は単調増加で あるため, 入力画像内の各画素の濃度值に関する大小関係 が保持されるという利点がある。

以上に述べたように，コントラスト改善処理において， 濃度のダイナミックレンジを広げるだけでなく，画像の空 間的特徵であるエッジを鮮明化することができれば，視覚 的により良好な結果画像が得られる可能性がある。提案手 法では, 濃度勾配分布ヒストグラムに基づいて, 入力画像 の各画素間の濃度差を拡大することを戦略とするコントラ スト改善を図る。

3. 濃度勾配ヒストグラムによるコントラスト 改善

〈3.1〉濃度勾配とコントラスト 图 5(a)は, 背景に対 して対象物が存在している場合の対象物上を通る水平線上 の濃度を表している。対象物領域と背景領域との濃度差が 大きいほど, 対象物は視覚的に識別しやすくなると考えら れる。この時, 対象物領域と背景領域との濃度差が大きい ほど, 両者の境界を意味するエッジにおける濃度勾配も大 きな値となる。また, 対象物と背景との濃度差は同一であ っても, 境界における濃度勾配が急峻な場合 (図 5(a)) と緩 


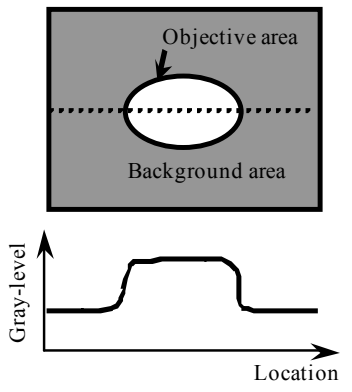

(a) Sharp edge
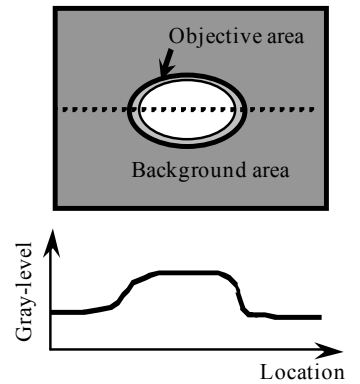

(b) Dull edge
図 5 濃度勾配とコントラスト

Fig. 5. Differential gray-levels and image contrast.

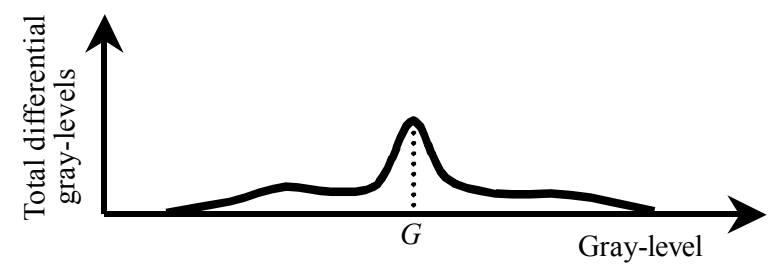

図 6 濃度勾配ヒストグラム

Fig. 6. Edge strength histogram.

やかな場合 (図 5(b)) を比較すると, 前者の方か輪郭線が明 瞭であり，視覚的にコントラストが高く感じる(10) (12)。この ように，濃度勾配情報は，濃度のダイナミックレンジとと もに，視覚的なコントラスト感に大きな影響を与えると考 えられる ${ }^{(13)}$ 。すなわち，画像に含まれる濃度勾配に着目し， エッジを境界とする両面の濃度差を広げることができれ ば，結果的に濃度勾配は大きくなり，効果的なコントラス 卜改善が期待できる。

〈3.2〉 濃度勾配ヒストグラム 入力画像の濃度分布 に基づく従来のコントラスト改善手法では, 横軸が濃度值， 縦軸が画素数を表す濃度分布ヒストグラムを利用する ${ }^{(1)}(7)$ 。 これに対して，提案手法では，図 6 に示すように，横軸が 濃度值, 縦軸が総合濃度勾配值を表す濃度勾配ヒストグラ ムから, 入力画像と出力画像間の濃度変換関数を生成する。 ここで, 濃度勾配值とは, 近傍画素領域内における濃度の 1 次微分值とする。縦軸の総合濃度勾配値とは, 产の濃度値 を持つ画素における濃度勾配值を累積した值である。濃淡

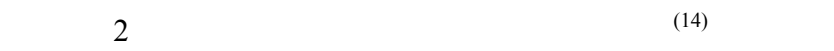
のようなヒストグラムにおける最大値に対応する濃度をし きい值とするが，ここでは濃度勾配ヒストグラムをコント ラスト改善に利用する。

図 6 に示すように，濃度勾配ヒストグラムに高頻度な部 分が存在する場合, この部分に対応する濃度值 $G$ は, 対象 物のエッジ上に位置する画素の濃度值である可能性が高 い。従って，濃度值 $G$ 付近の濃度範囲を優先的に拡張すれ ば, エッジによって分割されている 2 面間の濃度差が大き くなり，画像のコントラストは向上すると考えられる。以 下に, 具体的な濃度変換方法について説明する。図 7 に示 すように，濃度勾配ヒストグラムを濃度值の小さい方から

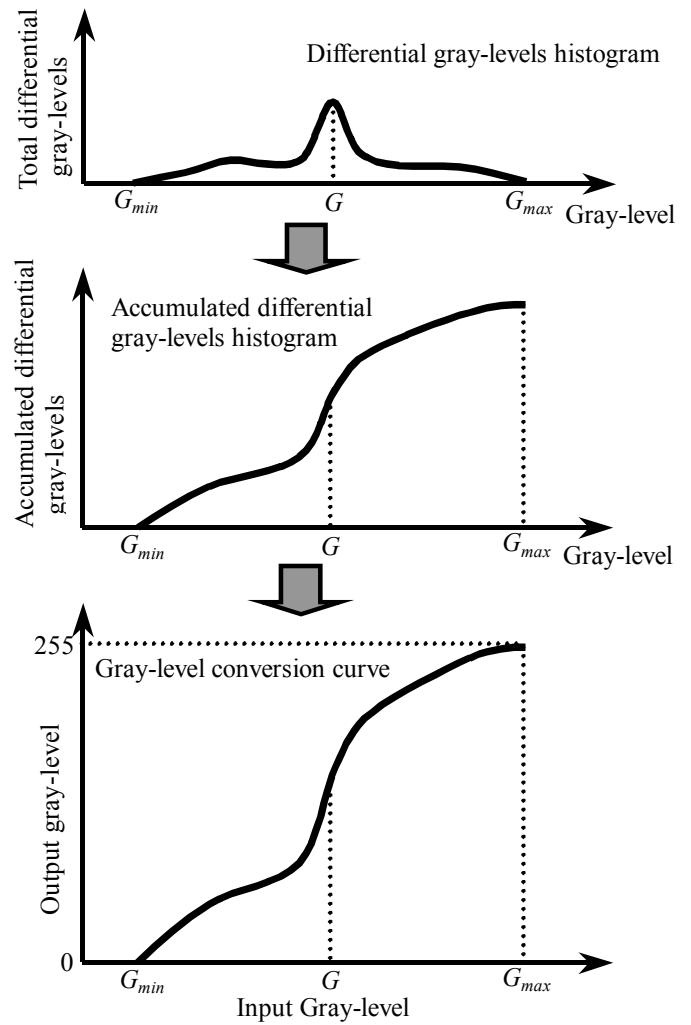

図 7 濃度勾配ヒストグラムから濃度变換曲線の生成

Fig. 7. Generation of gray-level conversion curve from differential gray-levels histogram.

順に累積した累積濃度勾配ヒストグラムを生成する。次に， この累積濃度勾配ヒストグラムの縦軸の最大值を出力画像 における最大濃度值となるように線形に正規化を行い，こ の曲線を入出力画像間の濃度変換関数とする。濃度勾配七 ストグラムにおいて, 高頻度な濃度 $G$ 付近では, 累積濃度 勾配ヒストグラムの勾配が大きくなるので, 入出力画像間 で濃度が大きく伸張されることになる。つまり，エッジ部 分の濃度差が伸張された出力画像が生成される。

簡略化した例として，図 8(a)に示すように，濃度が $G_{0}$ の 背景に濃度が $G_{1}$ の対象物領域があり, 更に光の中に濃度が $G_{2}$ の対象物領域が存在しているとする。背景と濃度 $G_{1}$ 領域 との間のエッジを構成する画素数を $N_{1}$, 濃度 $G_{1}$ 領域と濃度 $G_{2}$ 領域との間のエッジを構成する画素数を $N_{2}$ とする。この ような入力画像について濃度勾配ヒストグラムを生成する と図 8(b)のようになる。ここでは, 濃度勾配は簡略化のため， 濃度差 $G_{1}-G_{0}$ および $G_{2}-G_{1}$ としている。次に, 累積濃度勾配 ヒストグラムは図 8(c)のように, また , 入出力画像間の濃度 变換関数は图 $8(\mathrm{~d})$ のようになる。ここで, 入出力画像が取り える濃度範囲を 0 から 255 とし, 例えば, $G_{0}=0, G_{1}=10$, $G_{2}=255, N_{1}=100, N_{2}=10$ の場合を考える。濃度 $G_{1}$ 領域と背 景との濃度差が 10 と非常に小さいため, 視覚的には濃度 $G_{2}$ 領域だけが目立つ入力画像であることが予想される。こ の入力画像は, 既に濃度ダイナミックレンジが $G_{2}-G_{0}=255$ 


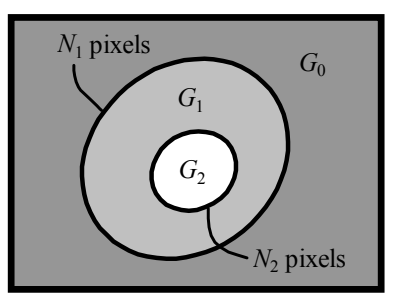

(a) Objective gray-scaled image

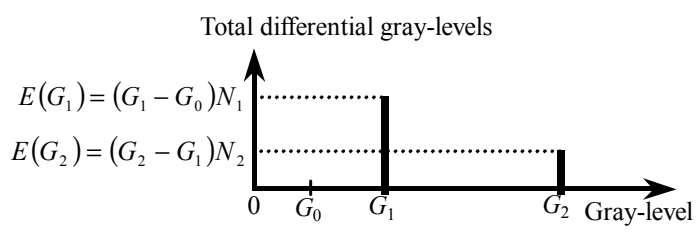

(b) Differential gray-levels histogram

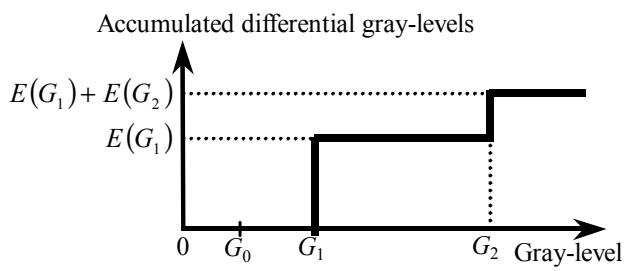

(c) Accumulated differential gray-levels histogram

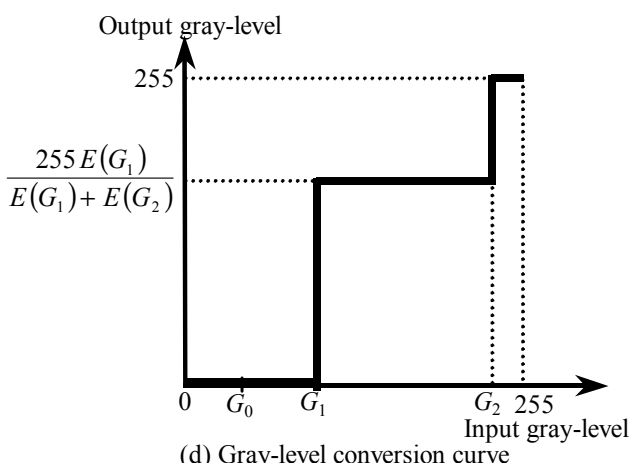

(d) Gray-level conversion curve

图 8 濃淡画像から濃度変換曲線の生成

Fig. 8. Generation of gray-level conversion curve from grayscaled image.

と最大であるので, 従来の濃度線形変換法では, 出力画像 は入力画像と同一であり，コントラストは改善されない。 上述の提案手法では, 背景と濃度 $G_{2}$ 領域の濃度は各々 0 と 255 と変化しない。しかし, 図 8(b)に示した濃度勾配ヒス卜 グラムの濃度 $G_{1}$ における総合濃度勾配値 $E\left(G_{1}\right)$ と濃度 $G_{2}$ に おける総合濃度勾配值 $E\left(G_{2}\right)$ は, 各々，

$$
\begin{aligned}
& E\left(G_{1}\right)=\left(G_{1}-G_{0}\right) N_{1}=(10-0) \times 100=1000 \\
& E\left(G_{2}\right)=\left(G_{2}-G_{1}\right) N_{2}=(255-10) \times 10=2450
\end{aligned}
$$

となり，濃度 $G_{1}$ 領域の濃度は，图 8(d)に示した濃度変換関 数から,

$$
O\left(G_{1}\right)=\frac{255 E\left(G_{1}\right)}{E\left(G_{1}\right)+E\left(G_{2}\right)}=74
$$

に変換される。背景と濃度 $G_{1}$ 領域間の濃度差は, 10 から 74 と大幅に増加し, 濃度 $G_{1}$ 領域のコントラストは向上する
ことになる。

$\langle 3 \cdot 3\rangle$ 濃度変換処理 以上に述べた提案手法におい て, 入力画像の濃度から出力画像の濃度に変換する具体的 な方法について述べる。一般の濃度分布ヒストグラムの場 合は, ある濃度値 $G$ における頻度值, すなわち, 濃度値 $G$ を持つ画素数 $N(G)$ は，次式によって得られる。

$$
\begin{aligned}
& N(G)=\sum_{x} \sum_{y} F_{G}(g(x, y)) \\
& F_{G}(g(x, y))= \begin{cases}1 & (\text { if } g(x, y)=G) \\
0 & \text { (otherwise) }\end{cases}
\end{aligned}
$$

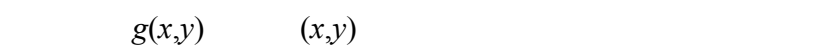
濃度勾配ヒストグラムの場合は, ある濃度値 $G$ における頻 度值, すなわち総合濃度勾配值 $E(G)$ は, 次式によって得ら れる。

$$
\begin{aligned}
& E(G)=\sum_{x} \sum_{y} F_{E}(e(x, y)) \\
& F_{E}(e(x, y))=\left\{\begin{array}{lc}
e(x, y) & \text { if } g(x, y)=G) \\
0 & \text { (otherwise) }
\end{array}\right.
\end{aligned}
$$

但し，e(x,y)は画素 $(x, y)$ における濃度勾配值である。ここで は, $e(x, y)$ は $3 \times 3$ 近傍画素間の 1 次微分フィルタとして知ら

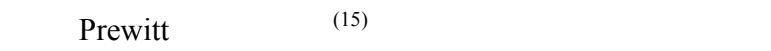

$$
\begin{aligned}
& e(x, y)=\sqrt{\delta_{x}(x, y)^{2}+\delta_{y}(x, y)^{2}} \cdots \cdots \cdots \cdots \cdots \cdots \cdots \cdots \cdots \cdots \cdots \cdots \cdots \cdots \cdots \cdots \cdots \\
& \delta_{x}=g(x+1, y-1)+g(x+1, y)+g(x+1, y+1)-g(x-1, y-1)-g(x-1, y)-g(x-1, y+1) \\
& \delta_{y}=g(x-1, y+1)+g(x, y+1)+g(x+1, y+1)-g(x-1, y-1)-g(x, y-1)-g(x+1, y-1)
\end{aligned}
$$

とする。次に, 累積濃度勾配ヒストグラムについては, 濃 度値 $G$ における頻度值, すなわち累積濃度勾配值 $A(G)$ は, 次式によって得られる。

$$
A(G)=\sum_{n=0}^{G} E(n) \cdots
$$

ここで, 入力画像内に含まれる最小濃度を $G_{\min }$, 最大濃度 を $G_{\max }$ とする。また, 出力画像の濃度範囲を 0 から 255 と する。入力画像のある濃度值 $G$ が出力画像の濃度値 $O(G)$ に 変換されるとすると,上式において, $A\left(G_{\min }\right)$ が 0 に,$A\left(G_{\max }\right)$ が 255 に線形変換される正規化が行われることから， $O(G)$ は次式によって求められる。

$$
O(G)=255 \frac{A(G)-A\left(G_{\min }\right)}{A\left(G_{\max }\right)-A\left(G_{\min }\right)}
$$

\section{3. 実験と 結果}

〈4·1〉実験条件提案手法によって, 図 9 に示した 6 種類の濃淡画像について, コントラスト改善を行った。画 像サイズは 256× 240 画素, 最大濃度階調は 256 レベルであ る。表 1 は,各画像に含まれる最小濃度 $G_{\min }$ と最大濃度 $G_{\max }$ の值を示す。(b)motor では， $G_{\min }=0, G_{\max }=255$ であるため， 入力画像の濃度ダイナミックレンジは既に最大となってい る。一方，(c)floppy では， $G_{\min }=0, G_{\max }=47$ と濃度ダイナミ ックレンジが狭く, コントラストも不良となっている。 


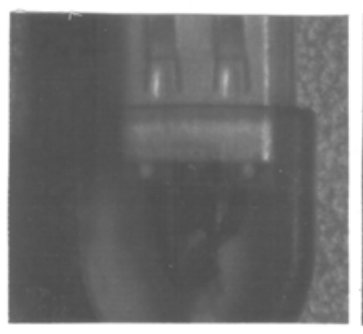

(a)connector

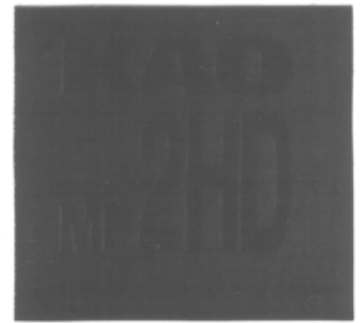

(c)floppy

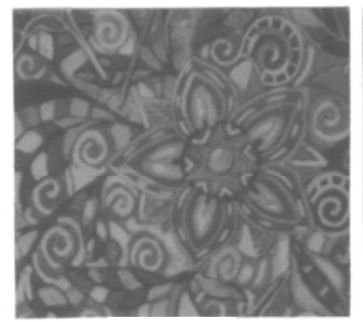

(e)pattern

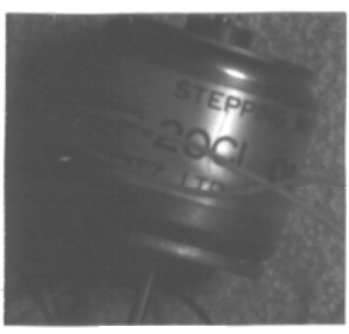

(b)motor

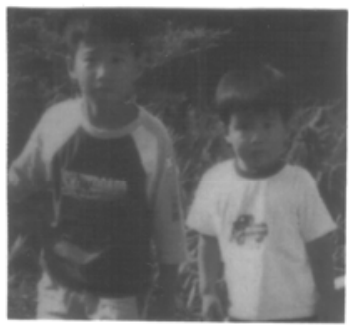

(d)children

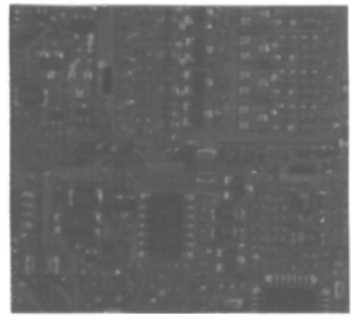

(f)circuit
図 9 実験画像

Fig. 9. Experimental images.

表 1 実験画像の濃度值

Table1. Gray-levels of experimental images.

\begin{tabular}{l|r|r|r}
\hline \multicolumn{1}{c|}{ Image } & \multicolumn{1}{|c|}{$G_{\min }$} & \multicolumn{1}{|c|}{$G_{\max }$} & $G_{\max }-G_{\min }$ \\
\hline (a)connector & 0 & 143 & 143 \\
\hline (b)motor & 0 & 255 & 255 \\
\hline (c)floppy & 0 & 47 & 47 \\
\hline (d)children & 0 & 171 & 171 \\
\hline (e)pattern & 36 & 162 & 126 \\
\hline (f)circuit & 21 & 181 & 160 \\
\hline
\end{tabular}

〈4·2〉 コントラスト改善結果图 10 は,コントラス 卜改善を行った結果画像を示す。提案手法との比較のため, 2 章で述べた代表的なコントラスト改善手法による結果も 提示している。各々の画像について, 左上が濃度線形变換 法, 右上が濃度分布ヒストグラムの正規分布化法, 左下が ヒストグラム均等化法，右下が提案手法による結果である。

まず， (a)connector では，濃度線形変換法は, 改善の効果 が少なく，視覚的にコントラスト感に乏しい印象を受ける。 ヒストグラム正規分布化法は, 比較的良好かつ自然なコン トラスト改善結果が得られている。ヒストグラム均等化法 は, コントラスト感が高く，コネクタ内部のワイヤが最も 明瞭に確認できるが, 過強調気味で, 特に明部に飽和傾向 が見られる。提案手法は, ヒストグラム正規分布化法と似 た結果であり，ワイヤ部分のコントラストはヒストグラム 均等化法と比べて劣るが，コネクタ上部の凹み部分のコン トラストは, 最も明瞭である。(b)motor では, 濃度線形変換
法は効果が見られないが，ヒストグラム正規分布化法は， モーター表面のコントラストは良好である。ヒストグラム 均等化法は画像全体に白飛びが発生しており，明らかに過 強調気味である。提案手法は, ヒストグラム正規分布化法 と比較して, モーター表面の文字や電線, および背景部分 がより明瞭であり，白飛びの発生も少ない。(c)floppy では， 文字部分のコントラスト感はヒストグラム正規分布化法が 良好である。ヒストグラム均等化法も文字部分は明瞭であ るが, 背景部分に白飛びが発生している。提案手法は, 文 字部分のコントラストは若干劣るが, プラスチック表面の 微妙なテクスチャは明瞭である。但し, ヒストグラム正規 分布化法と比べて,やや過強調気味ともいえる。(d)children では,やはり濃度線形変換法は効果が少なく, ヒストグラ ム均等化法は明部が過強調気味である。ヒストグラム正規 分布化法と提案手法はほぼ同樣な傾向といえるが，衣服の 模樣などは提案手法の方がコントラストが高い。(e)pattern では, 濃度線形変換法とヒストグラム正規分布化法がほぼ 同樣な結果となっている。ヒストグラム均等化法は, より コントラスト感が高いが, 提案手法は更に輪郭部分が明瞭 で良好なコントラストが得られている。(f)circuitでは,他の 画像と同樣, 濃度線形変換法は効果が薄く, ヒストグラム 均等化法はコントラスト感は高いが，はんだ部分などの明 部に白飛びが発生しており，不自然さが残る。ヒストグラ 么正規分布化法は配線パタンが不明瞭である。提案手法は， ヒストグラム均等化法と同樣な傾向であるが, 過強調の度 合は抑制されており，視覚的にも自然な印象を受ける。

$\langle 4 \cdot 3\rangle$ 従来手法との比較 以上に示した実験結果か ら, 各々の手法の全般的な傾向について考察する。濃度線 形変換法は, 過強調が少なく, 自然な印象を受けるが, 入 力画像のダイナミックレンジが広い場合は, ほとんど効果 が期待できない。ヒストグラム正規分布化法は, 自然さと コントラスト感のバランスに優れるが , 細かな画像パタン やテクスチャ部分が不鮮明になる場合が見られる。ヒスト グラム均等化法は, 視覚的なコントラスト感は高いが, 白 飛びが発生しやすいなどの不自然さや過強調気味の印象を 受け，また，画像によっては，特に均一な濃度領域におい てノイズが目立つ。一方, 提案手法は, 濃度線形変換法と 比較すると, コントラストの改善効果は顕著であり，ヒス トグラム正規分布化法とヒストグラム均等化法の中間的な 結果が得られている。すなわち, ヒストグラム正規分布化 法と比較すると細部のパタンやテクスチャの表現に優れる 一方で, ヒストグラム均等化法ほど強調度合は大きくない。 細部の画像パタンが鮮明でコントラスト感に優れるととも に, 明部の白飛びがヒストグラム均等化法に比べて抑制さ れており，自然な印象の結果画像が得られているといえる。 提案手法は，濃度勾配の分布に基づいて濃度変換を行う ため, (b)motorのように，照明光によるハイライトや逆光な どの影響から, ダイナミックレンジが充分広いにもかかわ らず，暗部の階調表現が不十分な画像に特に有効性が高い と考えられる。また, エッジ成分を多く含む(e)pattern や 


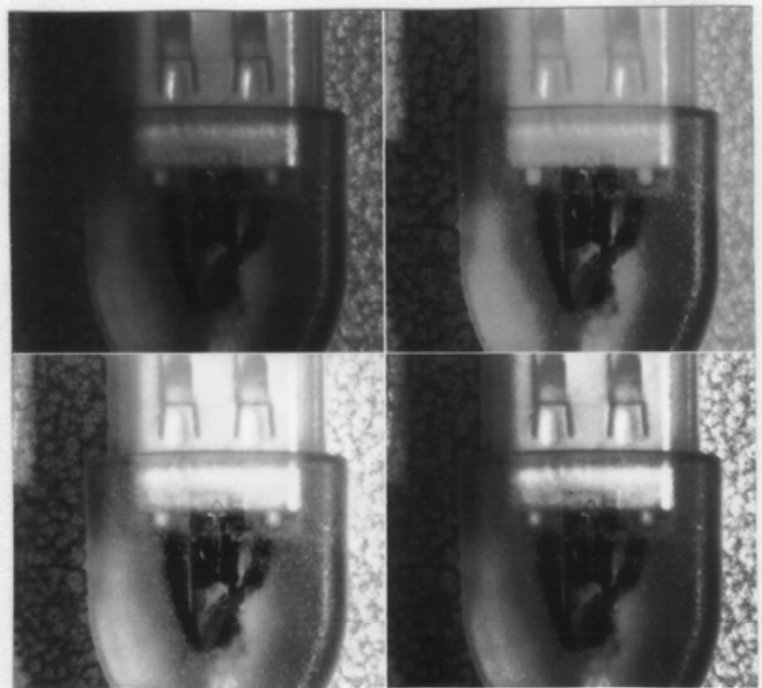

(a)connector

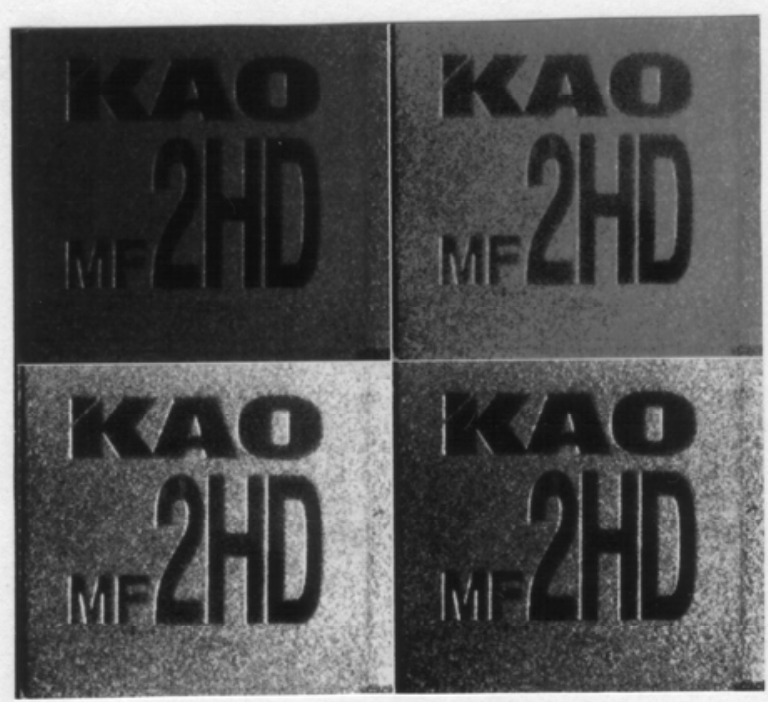

(c)floppy

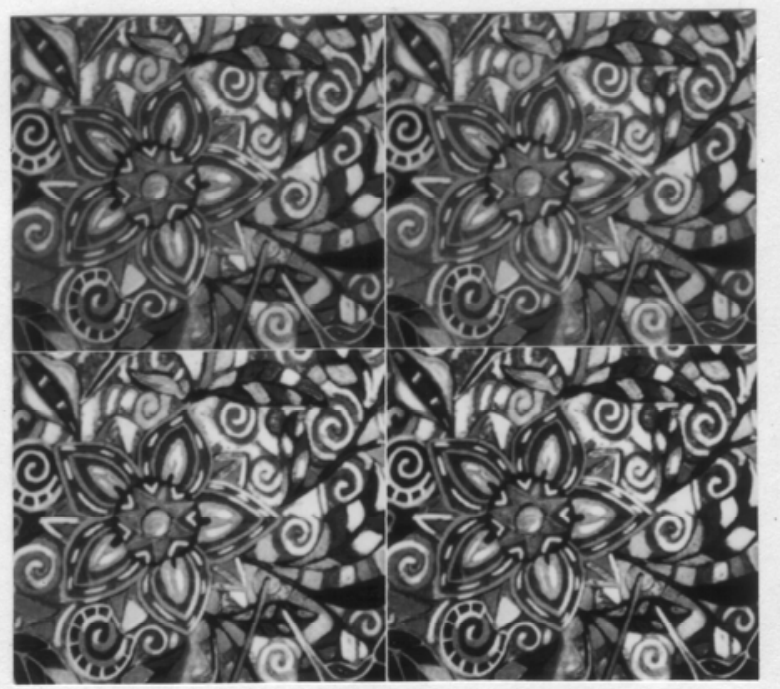

(e)pattern

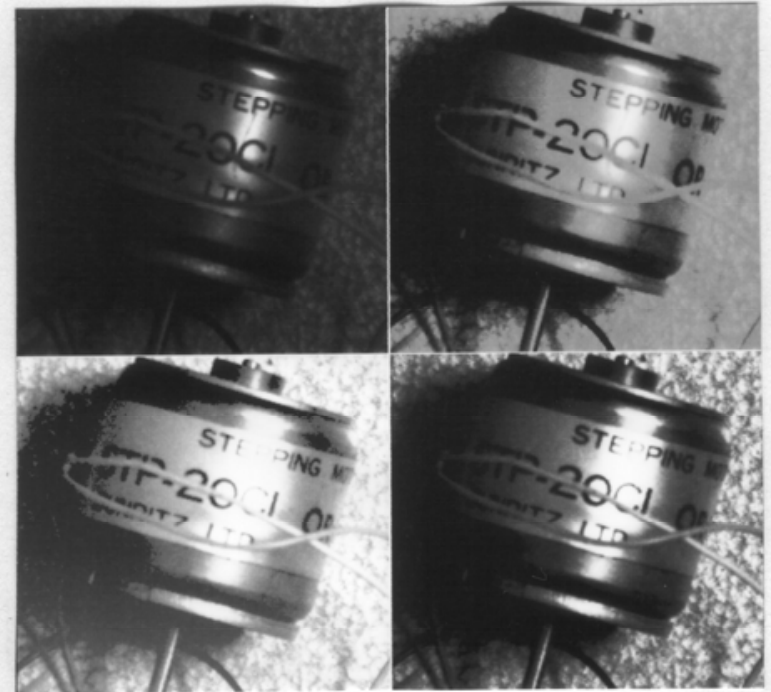

(b)motor

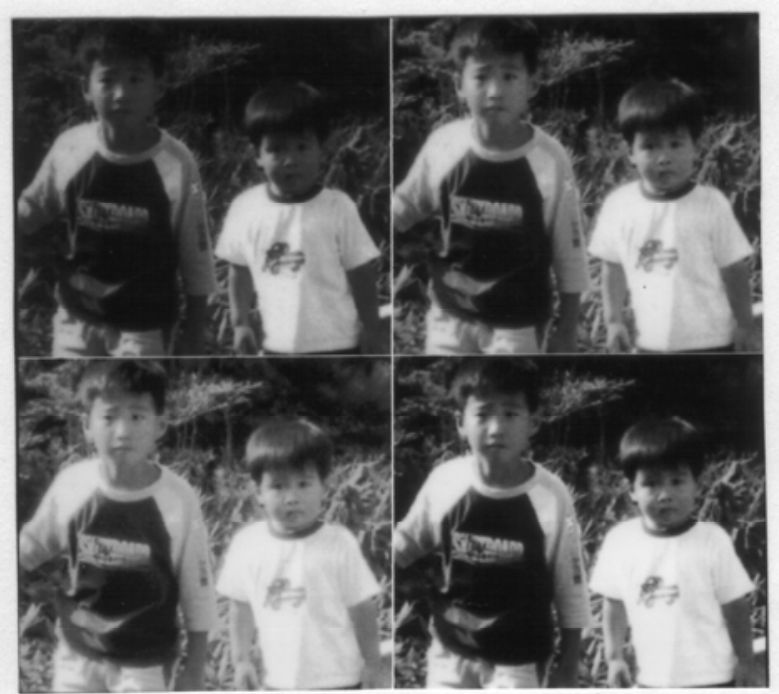

(d)children

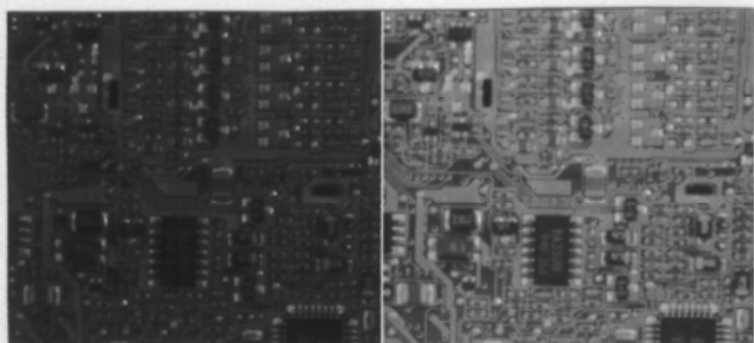

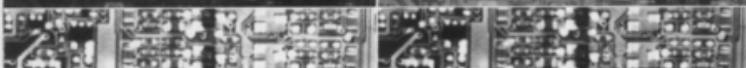
1.

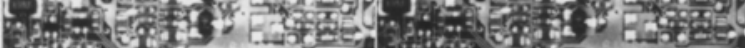

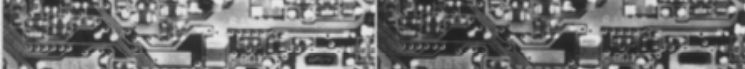

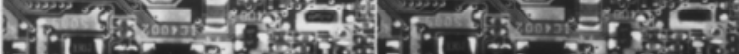

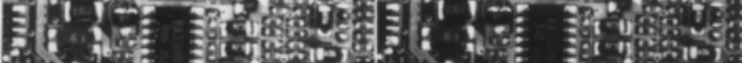

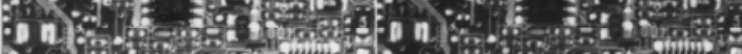
Q (f)circuit

図 10 コントラスト改善結果(左上:濃度線形変換, 右上:ヒストグラム正規分布化, 左下:ヒストグラム均等化, 右下:提案手法)

Fig. 10. Contrast improved images (upper-left: linear gray-level conversion, upper-right: histogram normalization, lower-left: histogram equalization, lower-right: proposed method) 

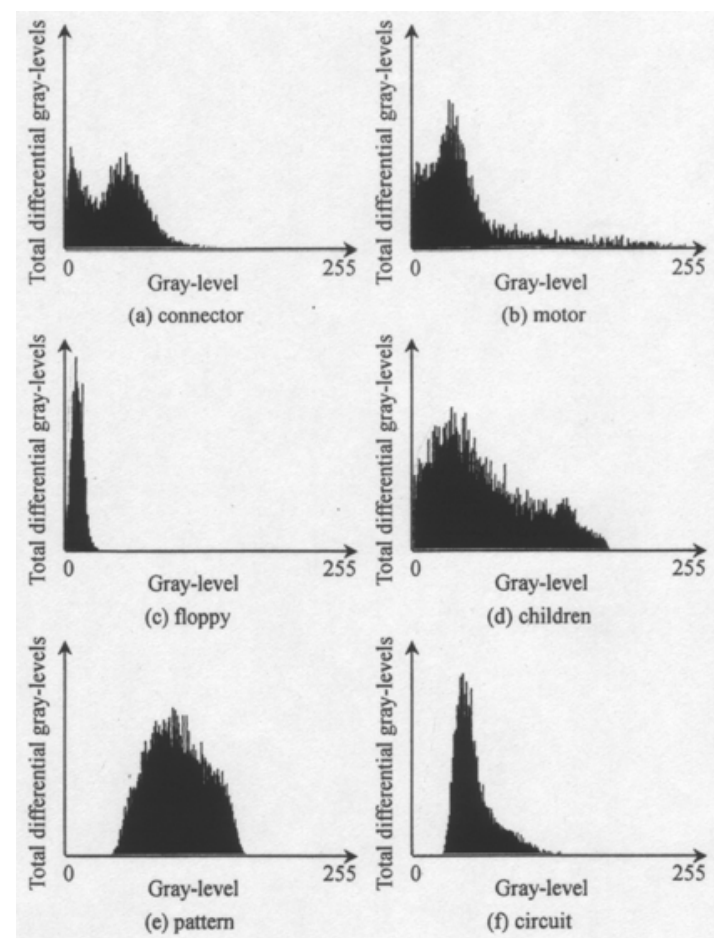

図 11 濃度勾配ヒストグラム

Fig. 11. Histograms to represent total differential graylevels.

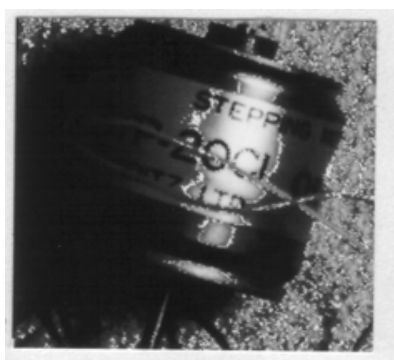

(b) motor

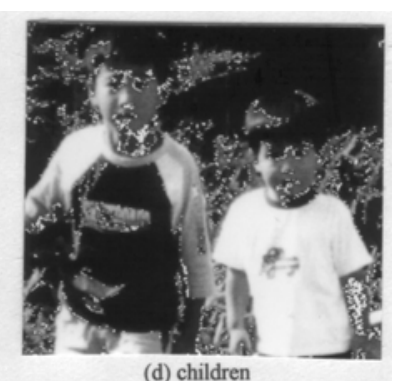

(d) children
図 12 ピーク周辺の濃度を持つ画素

Fig. 12. Pixels which have gray-levels around peaks.

(f)circuit のような画像にも適しているといえる。一方， (c)floppy のように，ほぼ均一な濃度面を多く含む画像では， この濃度面のテクスチャを明瞭にする効果が働くため，や や過強調気味となる場合がある。

濃度線形変換法とヒストグラム均等化法は, コントラス 卜強調のための最も一般的な手法として広く知られてお り，使用頻度も高い手法である。提案手法は，これらの従 来手法と比較して，常に視覚的に優れた結果が得られるわ けでない。しかしながら，コントラスト改善の効果，汎用 性，および手法の単純さに関して，従来手法と並んで，提 案手法を試みる価值は充分にあると考えられる。濃度線形 变換法やヒストグラム均等化法では，画像を複数領域に分 割したり ${ }^{(16)}$ ，画像の局所領域内の濃度情報を用いる改良手 法 ${ }^{(17)}$ などか提案されている。提案手法についても，同樣な 処理を施すことによって，より有効性を高められる可能性
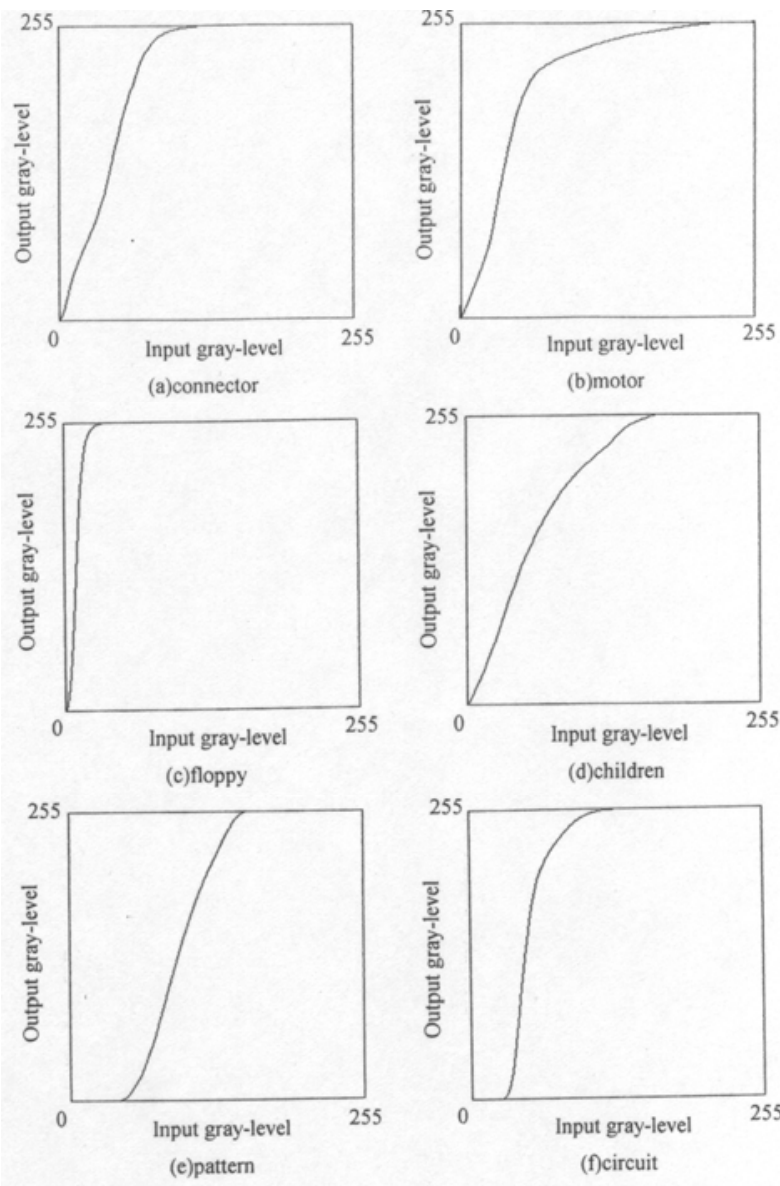

図 13 生成された濃度変換曲線

Fig. 13. Generated gray-level conversion curves.

があるが , 今後の検討課題である。

〈4·4〉 濃度勾配ヒストグラムと濃度変換曲線图 11 は, 各々の画像について得られた濃度勾配ヒストグラムを 示す。いずれの画像についても，ヒストグラムにはピーク となる峰部分が見られた。最大ピークを示した濃度は， (a)connector が 4 , (b)motor が 32 , (c)floppy が 6 , (d)children が 32 , (e)pattern が 92 , (f)circuit が 43 であった。く3·3〉で 述べたように, 濃度変換曲線は, 濃度勾配ヒストグラムか ら生成されるため, これらのヒストグラムのピーク部分に 当たる濃度付近において, 優先的に濃度の伸張が行われる ことになる。参考として, 図 12 は, (b)motor と(d)children について, 濃度勾配ヒストグラムのピーク濃度 \pm 1 範囲内の 濃度を持つ画素を白画素として提示している。(b)motor で は, モーター表面のハイライト部の境界やコードの輪郭， 背景パタンのエッジなどがピーク付近の濃度に該当してい ることがわかる。また, (d)children では, 人物の目, 鼻, 口 や, 背景の植物の葉のエッジ部分などが特に強調された部 分であることがわかる。

図 13 は, 各々の画像について得られた入出力変換曲線を 示す。横軸が入力画像の濃度, 縦軸が出力画像の濃度を表 す。例えば，(b)motor では，低濃度付近が極めて伸張されて おり，逆に高濃度部分は緩やかな勾配となっている。一方， 
表 2 結果画像の $D V$ と $B V$

Table 2. $\quad D V$ and $B V$ of resultant images.

\begin{tabular}{|c|c|c|c|c|c|c|}
\hline Image & $\begin{array}{l}\mathrm{DV} / \\
\mathrm{BV}\end{array}$ & $\begin{array}{c}\text { Original } \\
\text { image }\end{array}$ & LGC & $\mathrm{HN}$ & $\mathrm{HE}$ & DG \\
\hline \multirow{2}{*}{ (a)connector } & DV & 160.4 & 225.8 & 251.8 & 239.9 & 390.8 \\
\hline & BV & 11.9 & 17.4 & 32.9 & 40.3 & 28.7 \\
\hline \multirow{2}{*}{ (b)motor } & DV & 444.3 & 439.5 & 495.0 & 428.5 & 551.6 \\
\hline & BV & 13.9 & 13.9 & 16.7 & 26.7 & 19.6 \\
\hline \multirow{2}{*}{ (c)floppy } & DV & 106.7 & 322.5 & 385.2 & 656.1 & 689.7 \\
\hline & BV & 3.5 & 41.2 & 40.6 & 69.7 & 34.6 \\
\hline \multirow{2}{*}{ (d)children } & DV & 277.1 & 423.7 & 435.0 & 360.2 & 586.4 \\
\hline & BV & 21.2 & 24.3 & 24.8 & 34.5 & 20.7 \\
\hline \multirow{2}{*}{ (e)pattern } & DV & 237.5 & 732.0 & 720.8 & 1137.1 & 1369.6 \\
\hline & BV & 44.5 & 47.3 & 47.1 & 47.2 & 40.0 \\
\hline \multirow{2}{*}{ (f)circuit } & DV & 197.7 & 325.6 & 296.3 & 1425.2 & 1205.8 \\
\hline & BV & 23.0 & 38.3 & 49.0 & 41.7 & 35.6 \\
\hline
\end{tabular}

(e)pattern では, 中間濃度領域が伸張される傾向があるが， 比較的直線に近い形状の变換曲線が得られている。しかし， 濃度線形变換法のように完全な直線ではなく，各々の画像 について異なる特性を持つ変換曲線が生成されている。

〈4.5〉 DVと BVによる評価＼cjkstart画像のコントラスト感 を定量化することは困難であるが，DV (Detail Variance) と $B V$ (Background Variance) によって，画像の視覚的な鮮明さ を評価する方法が提案されている ${ }^{(18)(19)}$ 。 $D V$ と $B V$ は，次の ようにして求められる。まず, 各画素について, 近傍領域 内の濃度分散を求め, 閾値以上の場合は光の画素を前景に， 閾値未満の場合は背景にクラス分けする。光して，前景に 属する全画素に関する濃度分散の平均値を $D V$ とする。同樣 に, 背景に属する全画素に関する濃度分散の平均值を $B V$ と する。 $D V$ は局所的に濃度変化が大きな領域内の濃度分散を 表し, 逆に $B V$ は濃度の均一性が高い領域内の濃度分散を表 す。これらの值の性格から, 入力画像と比較して, $D V$ か増 加し, $B V$ か変化しない場合に, 明暗の変化か鮮明な結果画 像が得られていると考えることができる ${ }^{(18)(19)}$ 。

表 2 は, 各画像について, 入力画像, および, 従来手法 と提案手法による結果画像の $D V$ と $B V$ を計測した結果を示 す。近傍領域は $5 \times 5$ 画素, 閾値は 100 とした。提案手法(DG: Differential Gray-level)では , いずれの画像についても，従来 手法と比較して $D V$ が大きく，また， $B V$ も比較的低い值に 抑えられており，良好なコントラスト改善が行われている ことが示唆される。これに対して, 濃度線形変換法(LGC: Linear Gray-level Conversion)は, 全般的に $B V$ は入力画像と 近い值であるが， $D V$ は増加しない傾向があり，これが視覚 的にコントラスト感が乏しい理由と考えられる。ヒストグ ラム均等化法(HE: Histogram Equalization)は， $D V$ は大きい が, $B V$ も入力画像と比較して大幅に増加する傾向があり， これが過強調の要因であると考えられる。ヒストグラム正 規分布化法(HN: Histogram Normalization)は，濃度線形変換法 とヒストグラム均等化法の中間的な結果を示したが， $D V$ は 提案手法よりも低く, $B V$ は提案手法よりも高い傾向にあっ た。以上に述べた傾向は, 閾値を変化させても同樣であっ た . $D V$ と $B V$ の評価結果だけから画像のコントラストを定 量化することは困難であるが, これらの值は, 視覚的なコ ントラスト感と相関が高いことが報告されており ${ }^{(20)}$ ，提案
表 3 結果画像の $S F$ 値

Table 3. $S F$ values of resultant images.

\begin{tabular}{l|r|r|r|r|r}
\hline \hline \multicolumn{1}{c|}{ Image } & $\begin{array}{c}\text { Original } \\
\text { image }\end{array}$ & \multicolumn{1}{c|}{ LGC } & \multicolumn{1}{c|}{$\mathrm{HN}$} & \multicolumn{1}{c}{$\mathrm{HE}$} & \multicolumn{1}{c}{ DG } \\
\hline (a)connector & 10.2 & 18.0 & 25.8 & 38.4 & 31.7 \\
\hline (b)motor & 10.3 & 10.3 & 19.6 & 34.3 & 36.4 \\
\hline (c)floppy & 10.3 & 57.2 & 83.6 & 146.2 & 139.8 \\
\hline (d)children & 14.8 & 22.0 & 27.6 & 31.7 & 29.3 \\
\hline (e)pattern & 26.0 & 26.6 & 54.7 & 69.6 & 71.5 \\
\hline (f)circuit & 20.8 & 33.2 & 62.0 & 145.7 & 133.3 \\
\hline
\end{tabular}

手法によって，良好なコントラスト改善が行われているこ とが示唆される。

〈4·6〉 デルタヒストグラムによる評価次に, 結果 画像の鮮明度について, 前節で述べた $D V$ と $B V$ とは別の定 量的評価を試みた。ここでは, 自然画の鮮明度を表す尺度

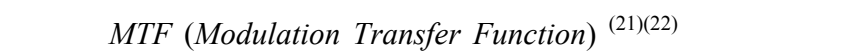
結果と高い相関があると報告されているデルタヒストグラ ムによる計測方法を用いた ${ }^{(23)}$ 。デルタヒストグラムは, 全 画素について, 周辺画素との平均濃度差をヒストグラム化 したものである。すなわち，濃度値 $g(x, y)$ を持つある画素 $(x, y)$ について, 8 近傍画素間との絶対濃度差の平均值 $H(x, y)$ を次 式によって求める。

$$
H(x, y)=\frac{1}{8} \sum_{j=-1 i=-1}^{1} \sum_{i=1}^{1}|g(x, y)-g(x+j, y+i)| .
$$

全画素について，横軸に $H(x, y)$, 縦軸に画素数を示す累積ヒ ストグラムを作成し,デルタヒストグラム $D_{o}$ とする。一方， ガウシアンフィルタを施した平均化画像について, 同樣に デルタヒストグラム $D_{b}$ を得て , デルタヒストグラム $D_{o}$ と $D_{b}$ との差 $S F$ (Sharpness Factor)を次式によって求める。

$$
S F=\frac{1}{N_{P}} \sum_{n=0}^{255}\left|D_{O}(n)-D_{b}(n)\right| \cdot
$$

ここで, $N_{P}$ は全画素数である。画像の鮮明度が高い場合は， ガウシアンフィルタによるぼけ具合が大きくなるため，デ ルタヒストグラムの変化が著しくなり $S F$ 值は大きくなる。 一方, 画像の鮮明度が低い場合は, 平均化処理による変化 か顕著ではないため, $S F$ 值は小さくなる。

表 3 は, 入力画像および各手法による結果画像について， $S F$ 值を計測した結果を示す。提案手法 $(\mathrm{DG})$ は, 濃度線形変 換法(LGC)とヒストグラム正規分布化法 $(\mathrm{HN})$ と比較して, 高 いSF值が得られた。また, 提案手法とヒストグラム均等化 法による $S F$ 值はほぼ同程度であり，提案手法は，ヒストグ ラム均等化法と同程度の鮮明さが得られているといえる。

〈4.7〉 微分フィルタについて 以上に述べた実験で は, 提案手法における微分フィルタとして, Prewitt オペレ 一タを用いた。ここでは, 画像処理で用いられる代表的な 1 次微分フィルタの種類が結果画像に与える影響を評価し た。図 14 は, 参考として, (d)childrenについて, Prewitt, Roberts，Sobel，Robinsonの各オペレータを用いた場合に生 成された濃度変換曲線を示す。フィルタの種類を変化させ ても, 濃度変換曲線の形状は安定していることがわかる。 表 4 は, 各々のフィルタによる結果画像の $D V$ と $B V$ ，およ び $S F$ 值を示す。いずれの值もフィルタの種類の影響をほと 

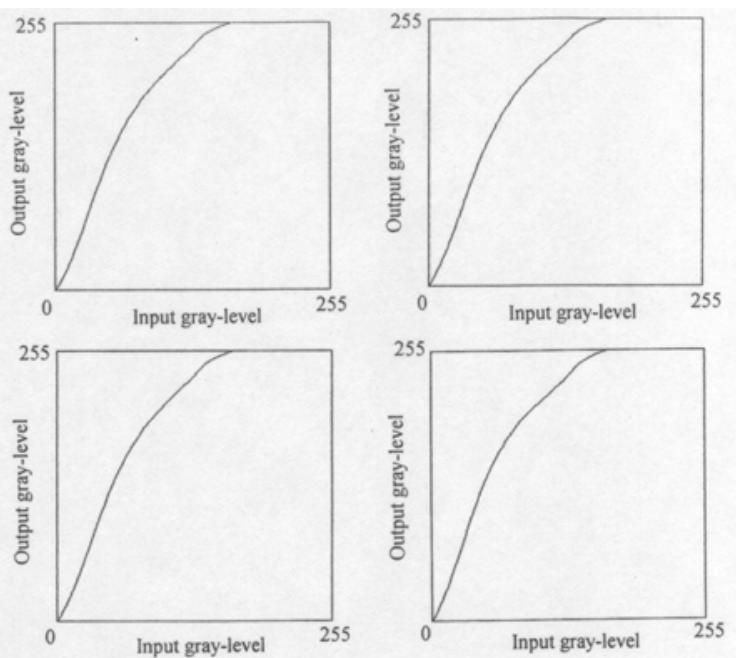

図 14 微分才ペレータと濃度变換曲線の関係(左上 : Prewitt, 右上 : Roberts, 左下: Sobel, 右下 : Robinson).

Fig. 14. Relation between gradient operators and gray-level conversion curves (upper-left: Prewitt, upper-right: Roberts, lower-left: Sobel, lower-right: Robinson).

\section{表 4 微分オペレータと $D V, B V, S F$ 値の関係}

Table 4. Relation between gradient operators and $D V, B V$ and $S F$ values.

\begin{tabular}{c|l|c|c|c}
\hline \hline Image & Gradient operator & $D V$ & $B V$ & $S F$ \\
\hline \multirow{4}{*}{ (d)children } & Prewitt & 586.4 & 20.7 & 29.3 \\
\cline { 2 - 5 } & Roberts & 585.8 & 21.1 & 29.2 \\
\cline { 2 - 5 } & Sobel & 587.5 & 20.9 & 29.1 \\
\cline { 2 - 5 } & Robinson & 583.3 & 21.2 & 29.6 \\
\hline
\end{tabular}

んど受けていない。他の画像についても同樣な結果であつ た。以上の結果から，フィルタの種類は結果画像にほとん ど影響を与えないことがわかった。

\section{4. まとめ}

濃度勾配ヒストグラムに基づく画像の空間的特徵を利用 したコントラスト改善手法を提案した。各画素における濃 度勾配の累積値から，局所的な濃度差を増大させる濃度変 換曲線を生成する。従来手法と比較して，視覚的なコント ラスト感が良好でかつ過強調が抑制された結果画像が得ら れた。また，コントラストと鮮明さについて定量的な評価 を試みた結果 , 従来手法と同等以上の結果が得られた。コ ントラスト改善処理を行う際，外部パラメータが不要な点 も提案手法の利点である。濃度線形変換法 , ヒストグラム 均等化法などの代表的手法と並んで，提案手法は，コント ラスト改善を行う場合の有力な候補になると考えられる。 今後は , カラー画像への適用を検討する予定である。

(平成 17 年 3 月 24 日受付, 平成 17 年 10 月 3 日再受付)

$$
\text { 文献 }
$$

(1) A.Rosenfeld and A.C.Kak : "Digital Picture Processing", Academic Press (1976)
( 2 ) R.Hummel : "Image Enhancement by Histogram Transformation", CGIP, Vol.6, pp.184-195 (1977)

( 3 ) E.L.Hall, R.P.Kruger, S.J.Dwyer, R.W.McLaren, and G.S.Lodwck : "A Survey of Preprocessing and Feature Extraction Techniques for Radiographic Images”, IEEE Trans. on computer, Vol.C-20, pp.1032-1044 (1971)

（4）松山隆司 : 画像解析の手法 (1) 前処理, 画像処理ハンドブック (尾 上守夫 (編))，第 11 章, 昭晃堂 (1987)

（5）輿水大和：濃淡画像と画質改善・画質強調, コンピュータビジョン (谷内田正彦 (編))，第3 章, 丸善 (1990)

(6) E.L.Hall : "Digital Image Processing and Pattern Recognition”, Academic Press (1979)

（7）高木幹雄・下田陽久 (監修)! 新編画像解析ハンドブック”,第 4 章, 東京大学出版社 (2004)

（8）河田 聡・南 茂夫: 科学計測のための画像データ処理, 第 5 章, C Q出版社 (1994)

（9）田村秀行 (編) : コンピュータ画像処理, 第 4 章, オーム社 (2002)

(10) 樋渡涓二 : 感覚と工学, 第 6 章, 共立出版 (1976)

(11) 本庄 知：画質評価, 画像電子ハンドブック, 第 11 章, コロナ社 (1993)

(12) D.Marr and E.Hildreth : "Theory of Edge Detection", Procs. of the Royal Society of London, B207, pp.187-217 (1980)

(13) F.Saitoh : "An Analysis of Spatial Features for Image Contrast Enhancement", Trans. of IEEJ, Vol.120-C, No.10, pp.1372-1379 (2000-10) (in Japanese)

斉藤文彦 :「コントラスト強調のための空間的特徵に関する考察」, 電学論 C, 120, 10, pp.1372-1379 (2000-10)

(14) 高木幹雄・下田陽久 (監) : 画像解析ハンドブック, 機能編第 2 章, 東京大学出版会. pp.502-504 (1991)

(15) D.H.Ballard and C.M.Brown : "Computer Vision", Prentice-Hall, Inc. Englewood Cliffs (1982)

(16) N.Kobayashi, H.Saito, and M.Nakajima : "Fast Adaptive Contrast Enhancement Method for the Display of Gray-Tone Images", Trans. of IEICE, Vol.J80-D- II, No.3, pp.502-509 (1994-3) (in Japanese) 小林直樹・斎藤英雄・中島真人 : 「自然画像表示のための高速な局所 的コントラスト強調」,信学論(D- II ),J77-D- II , 3, pp.502-509 (1994-3)

(17) F.Saitoh : "Local Contrast Enhancement by Optimizing Image Separation Using Genetic Algorithm", Trans. of IEEJ, Vol.121-C, No.10, pp.1508-1515 (2001-10)

(18) A.Vanzo, G.Ramponi, and G.L.Sicuranza : "An Image Enhancement Technique Using Polynomial Filters", Proc. of First IEEE Intern. Conf. in Image Processing, ICIP-94, pp.13-16 (1994)

(19) G.Ramponi : "A Simple Cubic Operator for Sharpening an Image", Proc. of 1995 IEEE Workshop on Nonlinear Signal and Image Processing, pp.963-966 (1995)

(20) K.Sugahara, H.Yamamoto, and R.Konishi : "Adaptive Image Enhancement Algorithm Based on the Fuzzy Set Operations", Trans. of IEICE, Vol.J80-D- II , No.7, pp.1786-1792 (1997-7) (in Japanese) 菅原一孔・山本久範・小西亮介 : 「ファジー理論に基づく適応的な画 像強調手法」, 信学論(D- II ), J80-D-II , 7, pp.1786-1792 (1995-7)

(21) J.C.Dainty and R.Shaw : "Image Science", Academic Press (1974)

(22) J.S.Arney, C.D.Arney, M.Katsube, and P.G.Engeldrum : "An MTF Analysis of Papers", Journal of Imaging Sci. Technol., Vol.40, No.61, pp.19-25 (1996)

(23) Y.Miyake, Y.Satoh, H.Yaguchi, and T.Igarashi : “An Evaluation of Image Quality for Color Images with Different Spatial Frequency Characteristics", Journal of Photogr. Sci., Vol.38, pp.118-122 (1990)

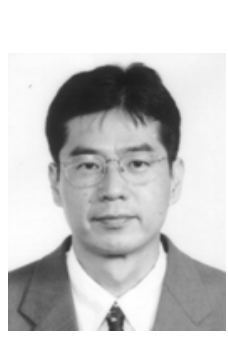

(正員) 1981 年慶大·工・数理卒。日本 IBM (株) 等を経て, 現在, 岐阜大学工学部応用情 報学科教授。視覚情報処理, 医用画像処理, マ シンビジョンの研究に従事。博士(情報科学, 工 学)。電子情報通信学会, 画像電子学会, 日本視 覚学会, 精密工学会等会員。 